\title{
There is no magic bullet: The importance of testing reference gene stability in RT-qPCR experiments across multiple closely related species
}

\author{
Bert Foquet $^{\text {Corresp., } 1}$, Hojun Song ${ }^{1}$ \\ ${ }^{1}$ Department of Entomology, Texas A\&M University, College station, Texas, United States of America \\ Corresponding Author: Bert Foquet \\ Email address: bertfoquet@tamu.edu
}

Reverse Transcriptase quantitative Polymerase Chain Reaction (RT-qPCR) is the current gold standard tool for the study of gene expression. This technique is highly dependent on the validation of reference genes, which exhibit stable expression levels among experimental conditions. Often, reference genes are assumed to be stable a priori without a rigorous test of gene stability. However, such an oversight can easily lead to misinterpreting expression levels of target genes if the references genes are in fact not stable across experimental conditions. Even though most gene expression studies focus on just one species, comparative studies of gene expression among closely related species can be very informative from an evolutionary perspective. In our study, we have attempted to find stable reference genes for four closely related species of grasshoppers (Orthoptera: Acrididae) that together exhibit a spectrum of density-dependent phenotypic plasticity. Gene stability was assessed for eight reference genes in two tissues, two experimental conditions and all four species. We observed clear differences in the stability ranking of these reference genes, both between tissues and between species. Additionally, the choice of reference genes clearly influenced the results of a gene expression experiment. We offer suggestions for the use of reference genes in further studies using these four species, which should be taken as a cautionary tale for future studies involving RT-qPCR in a comparative framework. 
1

2 There is no magic bullet: the importance of testing reference 3 gene stability in RT-qPCR experiments across multiple 4 closely related species

5

6

7

8

9

10

11

12

13

14

15

16

17

18

19

20

21

22

23

24

25

26

27

28

29

30

31

32

33

34

35

36

37

38

39

40

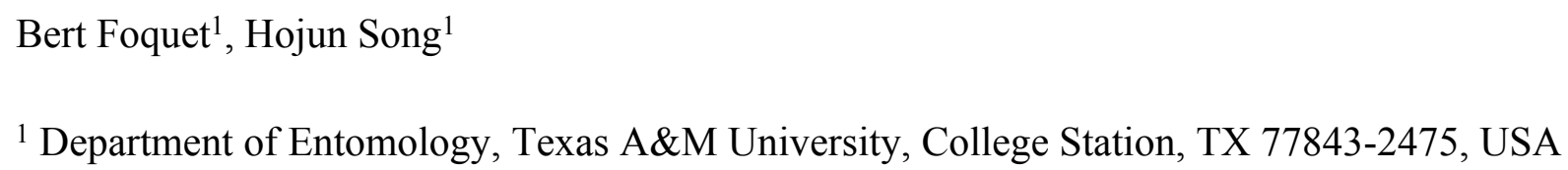




\section{Abstract}

42 Reverse Transcriptase quantitative Polymerase Chain Reaction (RT-qPCR) is the current gold standard tool for the study of gene expression. This technique is highly dependent on the validation of reference genes, which exhibit stable expression levels among experimental conditions. Often, reference genes are assumed to be stable a priori without a rigorous test of gene stability. However, such an oversight can easily lead to misinterpreting expression levels of target genes if the references genes are in fact not stable across experimental conditions. Even though most gene expression studies focus on just one species, comparative studies of gene expression among closely related species can be very informative from an evolutionary perspective. In our study, we have attempted to find stable reference genes for four closely related species of grasshoppers (Orthoptera: Acrididae) that together exhibit a spectrum of density-dependent phenotypic plasticity. Gene stability was assessed for eight reference genes in two tissues, two experimental conditions and all four species. We observed clear differences in the stability ranking of these reference genes, both between tissues and between species. Additionally, the choice of reference genes clearly influenced the results of a gene expression experiment. We offer suggestions for the use of reference genes in further studies using these four species, which should be taken as a cautionary tale for future studies involving RT-qPCR in a comparative framework.

\section{Introduction}

The current gold standard tool for studying gene expression at the RNA level is Reverse high sensitivity and speed of analysis (Gachon et al. 2004; Thellin et al. 2009). Nonetheless, qPCR accuracy is highly dependent upon the normalization of target gene expression with reference genes. An optimal reference gene should show minimal variability in its expression level between tissues, be unaffected by tested experimental factors, and exhibit similar expression levels as target genes (Vandesompele et al. 2002). Often those genes that are critical for maintaining basic cellular functions and expressed in all cell types, commonly referred to as housekeeping genes, are used as reference genes for qPCR experiments. Although qPCR is one of the basic tools employed in functional genetic research, mistakes in the experimental setup for qPCR experiments are surprisingly common, including the use of an inappropriate number of reference genes or the lack of accurate testing of reference gene performance under specific experimental conditions (Bustin et al. 2013; Gutierrez et al. 2008; Kozera \& Rapacz 2013). It is often the case that certain reference genes are selected for a particular qPCR experiment simply because they have been used previously, either for other experimental conditions or even in other tissues and species. This type of blind adoption of reference genes can result in inaccurate normalization of target gene expression, and ultimately in an incorrect interpretation of the results (Bustin et al. 2013; Dheda et al. 2004; Gutierrez et al. 2008; Nicot et al. 2005; Tricarico et al. 2002; Vandesompele et al. 2002). In response to these issues, the Minimum Information for Publication of Quantitative Real-Time PCR Experiments (MIQE)-guidelines, aiming to enhance the consistency of performing, interpreting, and reporting qPCR data, were formulated (Bustin et 
84 al. 2009). Additionally, several statistical algorithms have been developed to identify the best 85 reference genes to use under certain experimental conditions (Andersen et al. 2004; Hellemans et 86 al. 2007; Pfaffl et al. 2004; Vandesompele et al. 2002). Therefore, it is critical that a thorough investigation of reference gene stability is needed prior to setting up any qPCR experiment. While a vast majority of qPCR-based studies focus on gene expressions on a single species, there is a recognition that a comparative gene expression study across multiple closely related species that may have distinct biological or ecological differences can reveal important insights into the evolution of gene functions (e.g. Salazar-Jaramillo et al. 2017; Sørensen et al. 2019; Wittkopp et al. 2002). However, one of the assumptions in this type of comparative studies is that the reference genes that work well for one species must also work well for another closely related species. Although the reference genes are supposed to be stable within a species (Vandesompele et al. 2002), there is no a priori reason to believe that the same pattern is found in another species. If this assumption does not hold true, the subsequent inferences about the expression level of the gene of interest can be incorrect. Nevertheless, this assumption is rarely tested.

In this study, we explore the merit of this assumption by testing reference gene stability in qPCR experiments in four closely related species of grasshoppers in the genus Schistocerca (Orthoptera: Acrididae). Our initial motivation for this work comes from our long-term interest in understanding the molecular basis of density-dependent phenotypic plasticity in locusts. In short, locusts are grasshoppers that show an extreme form of density-dependent phenotypic plasticity in which relatively inactive and solitary individuals can transform into highly active and gregarious individuals in response to change in local population density (Cullen et al. 2017; Pener 1983; Pener \& Simpson 2009; Uvarov 1921). When the high density persists, locusts exhibit collective movements, which can lead to locust plagues (Pener \& Simpson 2009). These two density-dependent phenotypes are called the solitarious and gregarious phases (Pener \& Simpson 2009; Uvarov 1921), and understanding the molecular basis of this phenomenon has been considered the last frontier in locust research (Cullen et al. 2017; Pener \& Simpson 2009). We have been studying the Central American locust, Schistocerca piceifrons Walker, an important swarming locust species affecting Mexico and Central America (Barrientos Lozano et al. 1992; Bredo 1963; Harvey 1983), as a model system, which shows behavioral, morphological, physiological, ecological, and molecular plasticity in response to change in density, similar to its more well-studied congener, the desert locust $S$. gregaria (Forskål). Our research has shown that the Central American locust is more closely related to non-swarming grasshoppers than to other locust species within the genus (Song et al. 2017), and that these nonswarming relatives also show density-dependent phenotypic plasticity, reminiscent of the swarming locusts (Gotham \& Song 2013; Song et al. 2017). Therefore, over the past several years, we have been investigating the evolution of density-dependent phenotypic plasticity in a comparative framework by comparing transcriptomes of $S$. piceifrons and three other closely related Schistocerca species, which have led to the identification of some candidate genes that might be relevant for the expression of density-dependent phenotypes. It is in this context that we ask a question about the suitability of using the same reference genes for qPCR experiments across the four closely related species. In this study, we have designed and analyzed the stability of eight potential reference genes across the four species reared in two density conditions (isolated vs. crowded), and we demonstrate that the assumption of reference gene stability is not supported in our study system. We also validate our choice of reference genes with a set of four candidate genes in $S$. piceifrons by performing qPCR experiments. Finally, we provide a set of 
130 recommendations for selecting appropriate reference genes in a comparative analysis involving

131 multiple closely related species.

132

133

134

\section{Materials \& Methods}

136 Study insects and rearing regime

137 We used four closely related species in the genus Schistocerca, maintained as laboratory colonies

138 in the Department of Entomology at Texas A\&M University. The four species were: Central

139 American locust, S. piceifrons, and three sedentary species, S. americana (Drury), S. serialis

140 cubense (Saussure), and S. nitens (Thunberg). For conciseness, we use the species epithet

141 (piceifrons, americana, cubense, and nitens) throughout the paper. The piceifrons colony was

142 established from an outbreak population in Yucatan, Mexico collected in October 2015, and

143 imported under a USDA permit (USDA APHIS PPQ P526P-15-03851). The americana colony

144 was established from a population in Brooksville, Florida, collected in September 2010. The

145 cubense colony was established from a population in Islamorada in the Florida Keys collected in

146 January 2011. Finally, the nitens colony was established from a population in Terlingua, Texas,

147 collected in May, 2015. For this study, the colonies of these four species were reared under

148 crowded and isolated conditions. For the isolated condition, nymphs were isolated as hatchlings

149 and reared in separate plastic cages $(10.16 \times 10.16 \times 25.4 \mathrm{~cm})$ with one transparent side and

150 connected to a filtered positive airflow. For the crowded condition, both cage size and the

151 number of specimens depended on the species. For piceifrons, about 200 nymphs were kept in a

152 large cage $(40.64 \times 34.29 \times 52.07 \mathrm{~cm})$ in a USDA approved quarantine facility. For americana

153 and cubense, 150-200 nymphs were kept in larger cages $(30.48 \times 35.56 \times 50.8 \mathrm{~cm})$. For nitens,

154 over 50 individuals were kept together in a small cage $(30.48 \times 35.56 \times 50.8 \mathrm{~cm})$ because we

155 observed that the insects would die in the density used for other species. In both density

156 conditions, the insects were reared at 12 hours of light and 12 hours of darkness at $30^{\circ} \mathrm{C}$, and

157 were fed daily Romaine lettuce and wheat bran. We reared the insects until they molted to the

158 last nymphal instars to conduct qPCR experiments.

159

160 RNA extraction and $c D N A$ synthesis

161 Sample collection, RNA extraction and RNA quality assessment were performed as previously

162 described (Wang et al. 2020). Briefly, crowded-reared and isolated-reared female nymphs were

163 marked with a ceramic marker on the abdomen after molting to their last nymphal instar, and

164 were dissected around 72 hours later. Only specimens that molted before 10 AM were used, and

165 all dissections occurred between 8 and 9 AM. After removing gut tissues, head and thorax were

166 dissected using sterilized dissection scissors. Both tissues were preserved in RNAlater

167 (ThermoFisher Scientific) at $-20^{\circ} \mathrm{C}$, following the manufacturer's guideline. A total of 10

168 nymphs/density/species were dissected. Half of these was used for RNA sequencing, and the

169 other half was used for the qPCR experiment. Tissues were placed in MagNA Lyser Green

170 Beads (Roche) sample tubes and were homogenized for $30 \mathrm{~s}$ in $1 \mathrm{~mL}$ of Trizol (ThermoFisher

171 Scientific) using a MagNa Lyser instrument (Roche) at 6,500 rounds per minute. Whole-tissue

172 RNA was extracted using a Trizol-chloroform extraction, followed by clean-up with a RNeasy

173 mini kit (Qiagen) using an on-column DNAse treatment with a RNase-free DNAse set (Qiagen).

174 RNA concentrations were measured with a Denovix DS-11 spectrophotometer; 260/280 and

$175260 / 230$ values were above 2.0 for all samples. Additionally, microcapillary electrophoresis with

Peer] reviewing PDF | (2020:05:49192:1:1:NEW 24 Jun 2020) 
176 a Fragment Analyzer (Agilent Technologies RNA) was used to analyze RNA integrity of 177 samples destined for RNA sequencing. Only those samples with a RNA Quality Number (RQN)

178 over 3.9 were used. Due to differences in $28 \mathrm{~S}$ ribosomal RNA structure compared to other 179 eukaryotic species, RQN values for insects are often lower than what is generally considered a 180 valid threshold in mammalian samples (Escobar \& Hunt 2017, Macharia et al. 2015, Winnebeck 181 et al. 2010). Samples used for qPCR were diluted to a concentration of $100 \mathrm{ng}^{*} \mathrm{ml}^{-1}$ and

182 subsequently used to synthesize cDNA using the iScript cDNA synthesis kit (Bio-Rad) following

183

184

\section{$R N A$ sequencing and transcriptome assembly}

Both RNA sequencing and transcriptome assembly used for the present study were previously described in detail in Wang et al. (2020). Briefly, we generated RNA-seq data by performing paired-end sequencing (150 bp) on 8.5 lanes on an Illumina HiSeq4000 (San Diego, CA). Library preparation, sequencing, and read formatting was performed at Texas A\&M's AgriLife Research Genomics and Bioinformatics Service. After initial processing of raw data, raw reads were imported into a personalized Galaxy environment (Afgan et al. 2018) on a supercomputing cluster of the High-Performance Research Computing group of Texas A\&M University (Ada, https:// hprc.tamu.edu) for further processing, trimming, and quality control. FastQ Screen (Wingett \& Andrews 2018) was used to filter out sequences from the following potential contamination sources: (UniVec core (June 6, 2015), PhiX (NC_001422.1), Illumina adapters, Gregarina niphandrodes genome (GNI3), Encephalitozoon romaleae genome (ASM28003v2), Escherichia coli genome (K12), Methylobacterium sp., Bosea sp., Bradyrhizobium sp., Klebsiella pneumoniae, Sphingomonas sp., Rhodopseudomonas sp. and Propionibacterium acnes). We used Trinity (Grabherr et al. 2011) for de novo assembly, which was performed separately for each species and tissue. We further filtered the resulting assemblies using CD-hitEST (Fu et al. 2012; Li \& Godzik 2006) and Transrate (Smith-Unna et al. 2016). We assessed transcriptome quality using Trinitystats (Grabherr et al. 2011), BUSCO (Benchmarking Universal Single-Copy Orthologs; Simão et al. 2015), and by calculating the fraction of reads mapping back to the transcriptome with a combination of bowtie2 (Langmead \& Salzberg 2012; Langmead et al. 2009) and flagstat (Li 2011a; Li 2011b; Li et al. 2009).

Sequence assembly and expression analysis

All eight transcriptomes were imported into Geneious (R10.2.6; BioMatters, Ltd.). We selected nine potential reference genes: actin5C (Act5C), a-tubulin $(T u b)$, succinate dehydrogenase $(S D H)$, elongation factor $2(E F 2)$, ribosomal protein L5 (RIBL5), glyceraldehyde-3-phosphate dehydrogenase $(G A P D H)$, annexin IX (Ann), armadillo (Arm) and heat shock protein 70 (Hsp70). We also selected four target genes: pacifastin-related peptide 4, pacifastin-related peptide 5, allatostatin (ast), and allatotropin (at). For consistency, we followed suggestions by Simonet et al. (2004) for naming pacifastin-related peptides and named the Schistocerca piceifrons sequences $S P P P-4$ and $S P P P-5$. We obtained nucleotide sequences for all 13 genes from other orthopteran insects from Genbank (https://www.ncbi.nlm.nih.gov/genbank/) and used Megablast or tblastx with default settings in Geneious to find related sequences in our four species. For each gene, sequences of all four species were aligned using MUSCLE version 3.8.24 (Edgar 2004) in Geneious, with a maximum of nine iterations and default settings. Subsequently, sequences were manually curated, resulting in full-length coding sequences for each species. The identity of each gene was confirmed using the standard nucleotide Basic Local Alignment Search 
222 Tool (blastn) at the NCBI website, using the nr/nt database as reference (Altschul et al. 1990;

223 Johnson et al. 2008). Sequence information can be found in Table 1. Additionally, mapping reads

224 were counted as previously described (Wang et al., 2020), using bowtie2 (very sensitive end-to-

225 end, disable no-mixed and no-discordant behavior) and SAMtools' idxstats (Li et al. 2009) in

226 Galaxy. Differential expression analysis was performed with DEseq2 (Love et al. 2014) within

227 SARTools 1.7.1 (Varet et al. 2016), using R 3.5.3 (R Core Team 2017). All settings were kept at

228 their defaults; the expression in crowded-reared individuals was compared to that of conspecific

229 isolated-reared individuals.

230

231

\section{Primer design}

232

233

234

235

236

237

238

239

240

241

242

243

244

245

246

247

248

249

250

251

252

253

254

255

256

257

258

259

260

261

262

263

264

265

266

267

Primers for reference genes (Table 2) were designed using Primer3 (Koressaar \& Remm 2007; Untergasser et al. 2012), based on conserved regions, identified using the nucleotide alignment in Geneious. In this way, we aimed to generate primers that would work in all four species.

Standard settings were altered to an optimal melting temperature set at $60^{\circ} \mathrm{C}$, and the amplicon length at 150-200 bp. For the four target genes, primers were designed for just piceifrons, with identical settings in Primer3 as described above (Table 2). We designed three primer pairs for each gene. All sequences were ordered from Integrated DNA Technologies.

\section{Real time quantitative PCR and statistics}

For each qPCR reaction, $5 \mu 1$ of cDNA was added to $10 \mu 1$ of SsoAdvanced ${ }^{\mathrm{TM}}$ Universal

SYBR ${ }^{\circledR}$ Green Supermix (Bio-Rad \#1725275) and $5 \mu$ l of primers at a final concentration of 500 $\mathrm{nM}$. Every reaction was performed in duplicate or triplicate. To determine primer efficiency for reference genes, a dilution series of one sample was generated for each species by performing serial 10 -fold dilutions ranging from dilutions of $1 / 1$ to $1 / 10,000$. For the target genes, a 5-fold dilution series from $1 / 1$ to $1 / 3,125$ was used instead for determining primer efficiency. Based on these data, the most efficient primer pair was used in all further analyses. All other reactions were run on 96-well plates, with 10 samples (five isolated-reared individuals and five crowdedreared individuals) run on the same plate for a particular gene following the sample maximization method (Hellemans et al. 2007). Reactions were run on a CFX connect real time system (Bio-Rad) using the following thermal cycling profile: 3 minutes at $95^{\circ} \mathrm{C}, 40$ cycles of (1) 15 seconds at $95^{\circ} \mathrm{C}$ and (2) $45 \mathrm{~s}$ at $60^{\circ} \mathrm{C}$, and a melting curve from $65^{\circ} \mathrm{C}$ to $95^{\circ} \mathrm{C}$. $\mathrm{C}_{\mathrm{q}}$ values were exported from the Bio-Rad CFX manager using the default threshold.

For the analysis of reference gene stability, a total of five crowded-reared and five isolatedreared individuals per species were used for both head and thorax tissues. Gene stability was analyzed using three different programs: geNorm in qbase+ (Mestdagh et al. 2009; Vandesompele et al. 2002), Normfinder (Andersen et al. 2004), and Bestkeeper (Pfaffl et al. 2004). Raw $C_{q}$ values were used as input for BestKeeper and geNorm, while they were transformed to a linear scale for NormFinder. Gene efficiencies were assumed to be $100 \%$ for all tested genes (see Table 2 for actual gene efficiencies). To obtain a non-arbitrary ranking of reference genes, they were first ranked for each program separately, and subsequently the geometric mean of these scores was calculated as an accurate estimate of which reference genes were the most stable (Chen et al. 2011, Chen et al. 2013, Gong et al. 2016, Pereira-Fantini et al. 2016). The amount of reference genes needed to standardize gene expression was assessed using geNorm. Normalization factors were calculated in a stepwise manner, starting by taking the two most stable reference genes into account and adding another reference gene one by one.

Subsequently, the variation between these normalization factors were compared. If the difference

Peer] reviewing PDF | (2020:05:49192:1:1:NEW 24 Jun 2020) 
268 in variation is lower than 0.15 , the addition of an additional reference gene was deemed

269 unnecessary (Mestdagh et al. 2009; Vandesompele et al. 2002).

270 For the quantification of target gene expression, we used thorax tissues of five isolated-reared

271 and five crowded-reared individuals of piceifrons. Relative expression of target genes (ast, at,

$272 S P P P-4$, and $S P P P-5$ ) for thorax tissue in piceifrons was calculated with the $\Delta \Delta \mathrm{C}_{\mathrm{q}}$-method

273 (Livak \& Schmittgen 2001), using different sets of reference genes to normalize gene expression.

$274 P$-values were calculated with a two-tailed student t-test in R (version 3.6.2) based on non-

275 transformed $\Delta \mathrm{C}_{\mathrm{q}}$-values. All raw qPCR data can be found in Supplemental data S1-3, and the

276 code for the student t-test is present in Supplemental code S1.

277

278

279

280

\section{Results}

281

Selection of potential reference genes

282 A total of 9 potential reference genes were initially selected based on previous studies using

283

284 qPCR for locust gene expression research (Chapuis et al. 2011; Van Hiel et al. 2009; Yang et al. 2014). All of these genes were members of different functional categories (Table 1), with the

285

286

287

288

289

290

291

292

293

294

295

296

297

298

299

300

301

302

303

304

305

306

307 exception of the cytoskeleton genes, $T u b$ and $A c t 5 C$, which are both commonly used as reference genes in insect gene expression studies (Lü et al. 2018). We chose EF2 and RIBL5 over elongation factor $1 \alpha$ and other ribosomal genes, respectively, based on the low amount of variation for these genes in our transcriptome data. For 7 out of 9 genes, primer efficiencies for the selected primer pairs varied between 96 and $106 \%$ (Table 2). Two exceptions were Arm with an efficiency of $109.8 \%$ for piceifrons and $92.1 \%$ for nitens, and $S D H$ for which we were unable to find primers with sufficient efficiency values in all four species. We attribute this to a surprisingly high amount of sequence differences among the four species for $S D H$, effectively restricting the sequence regions that were conserved enough for primer design. As a result, $S D H$ was removed from all further analyses, and thus, only eight reference genes were used in further analyses. All included primer pairs showed melt curves with a single peak, suggesting the absence of aspecific amplification and contamination. $\mathrm{C}_{\mathrm{q}}$ values varied between 17.5 and 28.5, with GAPDH and $H s p 70$ having the lowest values and Arm having the highest.

\section{Comparing reference gene stability}

We subsequently compared the stability of these eight potential reference genes by performing qPCR reactions in five isolated-reared and five crowded-reared individuals for head and thorax tissues in all four species (Fig. 1). In americana, cubense, and nitens, all eight genes showed similar expression levels under the tested rearing conditions. However, in piceifrons, several genes showed a trend towards differential expression between the two density conditions. Specifically, Ann, Act5C, Tub, and $H s p 70$ showed a trend towards lower expression in the isolated condition for both tissues, while Arm and EF2 showed this trend only in the thorax tissue. RIBL5 was the only gene showing no difference between the two density conditions. We were able to confirm most of these observed trends with our transcriptome data (Table 3 ). The only discrepancies between our transcriptome data and the qPCR data were found for $H s p 70$ in

309

310

311

312 head tissue, GAPDH for thorax tissue, and Tub for both tissues. For thorax tissue, Act5C and Ann were even found to be significantly upregulated in crowded-reared individuals compared to isolated-reared individuals. 
313 Normfinder (Andersen et al. 2004) calculates both intra- and inter-group variations of gene 314 expression, and combines these into a stability value, and thus, genes with a lower rank are 315 considered to be more stably expressed. geNorm (Mestdagh et al. 2009; Vandesompele et al.

316 2002), the most popular algorithm, assumes that expression values of real reference genes are

317 perfectly correlated with each other in all tested samples. Based on this correlation, genes get a stability value ( $M$ value), with genes with $\mathrm{M}<1.5$ considered to be stable and the most stable gene obtaining the lowest score. BestKeeper (Pfaffl et al. 2004), on the other hand, outputs the standard deviation for each reference gene, expected to be lower than 1, and a correlation coefficient for each gene with the so-called BestKeeper-index, which is essentially the geometric mean of all stable reference genes. Before comparing the stability values, we estimated the amount of necessary reference genes for each species and tissue using geNorm's V-values. For americana, cubense, and nitens, geNorm suggested that using two reference genes was sufficient as its values for $\mathrm{V}_{2 / 3}$ were below 0.15 (Fig. 2). However, for piceifrons, the difference in variation between using two or three reference genes was higher than 0.15 for the head tissue and very close to 0.15 for the thorax tissue (Fig. 2). Thus, the use of three reference genes is suggested for this species. Overall, the three programs listed genes in a similar fashion, with only a few exceptions (Table 4, 5). Tub and GAPDH were the two least stable genes, and both were listed as the last in 3 out of the 8 tested species/tissue combinations. Act $5 C$ was to be the most stable reference gene overall, as it was generally listed in the top half of stability values by all three programs. Arm was also often listed in the top three of most stable genes, but was even listed as the seventh most stable gene in some cases (Normfinder, Bestkeeper in piceifrons head; Normfinder in nitens head).

For the americana head tissue, $A c t 5 C$ and $E F 2$ were the two most stable genes overall, with $A c t 5 C$ rated the most stable gene by each program, and $E F 2$ obtaining a second place for both geNorm and NormFinder. RIBL5 and Arm, which were also consistently ranked as stable reference genes, obtained a third and a fourth place. For the americana thorax tissue, RIBL5 and $E F 2$ were our two reference genes of choice, as they obtained a first and a second place overall. Additionally, Arm and Act5C were ranked as third and fourth overall, but obtained very similar stability scores to EF2 and were ranked in the first half by all three programs. For the cubense head tissue, both $A c t 5 C$ and $H s p 70$ were ranked within the top 3 most stable reference genes by all three programs and as a result, obtained top overall rankings. For the cubense thorax tissue, Hsp 70 obtained the best ranking, followed by Ann ranked second. Nonetheless, it should be noted that for this species and tissue combination, several reference genes obtained very similar scores for both NormFinder and geNorm, resulting in low rankings for some genes that were actually quite stable. For instance, $A c t 5 C$ was ranked as only fifth overall even though it performed very similar to Ann, which was ranked second. For the nitens head tissue, the rankings suggested by the three different programs disagreed strongly with each other, as Ann and Act5C were ranked first and second by geNorm and NormFinder, but fifth and fourth by BestKeeper, while Arm was ranked first by BestKeeper and sixth and seventh by the other two programs. Overall, Ann and $A c t 5 C$ were ranked first and second, and $H s p 70$, which was the only gene ranked within the first half by all three programs, was ranked as third. For the nitens thorax tissue, Ann and Arm were clearly the preferred reference genes as they were consistently ranked as the two most stable genes by all three programs. Finally, for both tissue of piceifrons, Act5C and Ann were ranked in the top 4 of most stable genes by all programs. RIBL5 and Arm were also ranked in the top 4 for head and thorax tissue respectively. 


\section{Validation of reference genes}

To explore how the choice of reference genes would affect the outcome of qPCR experiments, we quantified and compared the expression levels of the four target genes (ast, at, SPPP-4, and $S P P P-5$ ) using different reference genes in the thorax tissue of piceifrons reared in two density conditions. As $T u b$ was the least stable reference gene, it was not included for this analysis. Our data showed the choice of reference genes strongly affected the qPCR results (Fig. 3). Regardless of the reference genes used, ast showed a significantly higher expression level in isolated-reared individuals compared to crowded-reared individuals, and $S P P P-5$ never came close to reaching significant differences. When all of the reference genes (except $T u b$ ) were chosen, at and SPPP4 showed trends toward decreased and increased expression, respectively, in crowded-reared individuals ( $p=0.068$ and $p=0.061$, respectively). We subsequently removed RIBL5 from the analysis and thus only used reference genes of which the expression varied between both rearing conditions. As a result, the p-value for at dropped below 0.05, while the trend observed for $S P P P-4$ partially disappeared. Lastly, we included just $H s p 70, R I B L 5$ and $G A P D H$ as reference genes, which was our preferred set of reference genes based on the earlier data. As a result, $S P P P-4$ showed a significantly higher expression level in the crowded-reared condition, while no significant difference was observed for at anymore $(p=0.19)$. Three out of the four of these qPCR results agreed with our transcriptome data (Table 6).

\section{Discussion}

The overall goal of this study is to address the suitability of using the same reference genes for qPCR experiments across multiple closely related species. So far, only a handful of studies have compared reference gene stability between different species (e.g. Axtner \& Sommer 2009; Bonnet et al. 2013; Giménez et al. 2011; Lin et al. 2009; Weyrich et al. 2010). Many qPCR-based studies have simply used the reference genes designed and optimized for one species in a study involving another species without specifically testing for their gene stability (Bustin et al. 2013; Lin et al. 2009; Lü et al. 2018). In this study, we have compared the stability of eight potential reference genes across four Schistocerca species reared in two density conditions, and demonstrated that the reference gene stability cannot be assumed a priori in a comparative analysis across multiple species.

The choice of reference genes used in qPCR experiments is often guided by the genes used in prior studies, rather than by a comprehensive assessment of all available candidates. Lü et al. (2018) performed a meta-analysis on the selection of reference genes in insect qPCR experiments based on 90 papers published between 2013-2017, and showed that the same 10 reference genes were repeatedly used across 78 insects belonging to 10 different orders. There are certainly more than 10 reference genes available and we think that there could be hundreds or even thousands of potential reference genes in any given species. For example, there are over 3,800 genes that are expressed uniformly across tissues in humans (Eisenberg \& Levanon 2013), and hundreds of reference genes have been utilized in human gene expression studies. The reason why only a small number of reference genes are used in insect gene expression studies is probably because we do not fully understand gene contents and their expression patterns in most insects. Therefore, when designing qPCR experiments for non-model insect species, one has no other option but to rely on the previous studies to identify well-known reference genes. Our study was no exception. We selected our reference genes based on studies performed in other locust species, including the desert locust Schistocerca gregaria (Van Hiel et al. 2009), the migratory locust Locusta migratoria (Yang et al. 2014), and the Australian plague locust 
405 Chortoicetes terminifera (Chapuis et al. 2011). However, only one of these (Chapuis et al. 2011) 406 included rearing density as an experimental factor, and found Arm and Elongation Factor $1 \alpha$ as 407 the most stable reference genes, while GAPDH and $S D H$ were found to be the least stable. Even 408 though we did not test exactly the same genes, GAPDH is overall also one of the least stable 409 reference genes, while Arm is often found within the top 3 of most stable genes in our study. 410 This suggest that, to a certain degree, stable reference genes in one species can be expected to be 411 stable in a related species, even though there is a clear need for scrutiny as the reference gene 412 stability varied widely across both species and tissues in our study.

413 We have designed primers for eight reference genes that can be used across four species

414 of Schistocerca. In doing so, we observed an interesting trend when comparing primer

415 efficiencies between different species. As the four Schistocerca species used in our study are

416 closely related, we designed and tested a single primer pair per each gene that would work for all

417 four species. We consistently selected conserved gene regions for the primer design, and made

418 sure that the selected regions did not overlap with sites showing single nucleotide

419 polymorphisms. Nonetheless, the primer efficiencies for some primer pairs varied widely (Table

420 2). As such, it seems that a base pair difference in the amplicon, or maybe even upstream or 421 downstream of it, can influence the primer efficiency. This indicates that primer efficiencies

422

423

424

425

426

427

428

429

430

431

432

433

434

435

436

437

438

439

440

441

442

443 should always be tested for every species (or even subspecies/populations) included in a comparative study, even if those species are very closely related to each other.

After designing the primers for the reference genes and testing their efficiencies, we assayed their gene stability using three commonly used programs (NormFinder, geNorm, and BestKeeper). Interestingly, we found that different programs selected different genes as their top choices, and the results also depended on both tissue types and species (Tables 4 and 5). This discrepancy is probably due to the different algorithms employed by these programs.

We have also identified additional issues when these reference genes are used for a species exhibiting an extreme form of phenotypic plasticity. Of the four species analyzed in this study, piceifrons is the only swarming locust species, and can be expected to exhibit larger molecular differences between both density conditions than the other three species. It is thus feasible that several of the tested reference genes could also be influenced by the extreme form of density-dependent phenotypic plasticity. In fact, we report that several reference genes in piceifrons showed a trend towards differential expression. Additionally, geNorm predicted that the use of two reference genes would not be sufficient to perform a qPCR experiment for piceifrons, in contrast to what the program suggested for the other three species. All of the samples were given exactly the same treatment independent of rearing condition and were all diluted to $100 \mathrm{ng} / \mu \mathrm{l}$ before the cDNA synthesis. As such, we consider it unlikely that all isolated-reared samples somehow had lower RNA concentrations than the crowded-reared samples. Given the extreme form of density-dependent phenotypic plasticity in piceifrons, it is conceivable that some of the tested reference genes actually respond differentially to the rearing conditions. This idea was supported by our transcriptome data, where most genes exhibited a similar trend towards differential expression as found in our qPCR, and two genes even were significantly different between both rearing conditions (Table 3). These observations make the selection of suitable reference genes for piceifrons a lot more complicated compared to that for the other three species. To make the situation even worse, the algorithms used to select the most stable reference genes failed to select the right reference genes. This was especially evident for the thorax tissue in piceifrons, as the only gene not exhibiting different expression levels between both rearing conditions, RIBL5, was ranked as the $8^{\text {th }}$ most stable reference gene. Both 
451 geNorm and BestKeeper assume that perfect reference genes are strongly correlated to each other, and as a result they are susceptible to errors when the majority of the tested genes is actually influenced by the tested experimental conditions. Likewise, even though NormFinder takes both inter- and intra-group variation into account and should thus perform better under such conditions, this program ranked several genes showing a clear trend towards differential expression between rearing conditions as the most stable in piceifrons. Therefore, it is clearly not sufficient to only consider the overall stability values in selecting reference genes, but it is also important to take the actual $\mathrm{C}_{\mathrm{q}}$ values into account. Additionally, these findings suggest that we cannot simply use the same set of reference genes blindly across the species, but we must carefully consider the type of reference genes to be used for each species.

For all species, we followed the suggestions of the GeNorm analysis for determining the amount of reference genes. For piceifrons, we thus suggest three genes should be used, while for the other species, two reference genes should be sufficient. In piceifrons, Ann, Arm and Act5C should not be selected as the reference genes when studying differential gene expression between isolated-reared and crowded-reared individuals. For such a study, we suggest the use of RIBL5, $H s p 70$ and EF2 for the head tissue, and RIBL5, Hsp70 and GAPDH for the thorax tissue instead. Even though RIBL5 was listed as the last-ranked reference gene by all three programs for the thorax tissue, we consider its inclusion is still valid for two reasons. First, it is the only gene that shows no differential expression between the density conditions. Second, the standard deviation on this gene, reported by BestKeeper, is also one of the lowest, even though this variable was not included in our ranking. After selecting the reference genes according to what is presented above to normalize gene expression of the four target genes, our results matched well with the results of RNA-seq experiments. For the other three species, the choice of reference genes is more straightforward, as there was no discrepancy between the stability values and the $\mathrm{C}_{\mathrm{q}}$ values. Thus, we suggest the use of the two genes with the best overall stability ranking as reference genes in further studies. Our suggestions for each species are summarized in Table 7.

Two of the selected target genes for validation were pacifastins (SPPP-4 and SPPP-5), which are members of a family of peptidase inhibitors that exhibit differential expression between isolated-reared and crowded-reared individuals in S. gregaria (Badisco et al. 2011; Breugelmans et al. 2008; Breugelmans et al. 2009; Simonet et al. 2005; Simonet et al. 2004). We show that SPPP-4 expression in the thorax tissue from crowded-reared individuals is higher compared to isolated-reared individuals, and SPPP-5 shows a similar but a non-significant trend, consistent with earlier studies in S. gregaria (Badisco et al. 2011; Breugelmans et al. 2008; Simonet et al. 2005). The other two target genes were allatotropin, a pleiotropic hormone that is best known as a stimulator of juvenile hormone $(\mathrm{JH})$ production and a myostimulatory peptide (Kataoka et al. 1989; Lismont et al. 2015), and allatostatin, known to repress JH production in insects even though this function could not be confirmed in S. gregaria (Stay et al. 1995; Verlinden et al. 2009). We report that ast is significantly downregulated in crowded-reared locusts, and observed a similar but non-significant trend for at. We also note that these observations were not confirmed by our RNA sequencing data, where no significant differences were obtained for either of these two genes. Both ast and at exhibited very low expression levels, and the difference between both techniques might thus represent a difference in sensitivity between both techniques. Other differences between both technique (e.g RNA sequencing being more prone to PCR artefacts and positional bias) might play an additional role in the observed 
495

496

497

498

499

500

\section{Conclusions}

502

503

504

505

506

507

508

509

510

511

512

513

514

515

516

517

518

519

520

521

522

523

524

525

526

527

528

529

530

531

532

533

\section{References}

differences. An earlier study in $S$. gregaria reported no significant difference between isolatedreared and crowded-reared individuals for at (Lismont et al. 2015), even though the data were not shown. Together, our data might suggest differences in $\mathrm{JH}$ regulation between isolated-reared and crowded-reared locusts.

Our study is one of only few studies testing the stability of reference genes for qPCR in multiple species. When ranking reference genes based on their stability, we found clear differences between the four tested species. Additionally, all three used algorithms, geNorm, BestKeeper, and NormFinder, seemed to struggle when the majority of tested reference genes showed a trend towards differential expression in the tested experimental conditions. As such, stability values obtained by these algorithms should always be analyzed side by side with the raw $\mathrm{C}_{\mathrm{q}}$ values. Additionally, our study suggests that both qPCR primer efficiency and reference gene stability should always be tested separately for each species of interest. Not doing so might result in differences in amplification efficiencies and incorrect interpretation of the results.

\section{Acknowledgements}

We thank Mario Poot-Pech and the rest of the locust control team of the Comite Estatal de Sanidad Vegetal de Yucatán (CESVY), Mexico for their help in collecting piceifrons nymphs to establish our lab colony. We thank Ryan Selking, Charmelle Williams, and Sam Franklin for help with colony care, RNA extractions, and RT-qPCR. We thank Texas A\&M AgriLife Genomics and Bioinformatics Service for data generation and Michael Dickens at Texas A\&M High Performance Research Computing for installing all used tools into the Galaxy environment.

Afgan E, Baker D, Batut B, Van Den Beek M, Bouvier D, Čech M, Chilton J, Clements D, Coraor N, and Grüning BA. 2018. The Galaxy platform for accessible, reproducible and collaborative biomedical analyses: 2018 update. Nucleic acids research 46:W537-W544.

Altschul SF, Gish W, Miller W, Myers EW, and Lipman DJ. 1990. Basic local alignment search tool. Journal of molecular biology 215:403-410. 
534 Andersen CL, Jensen JL, and Ørntoft TF. 2004. Normalization of real-time quantitative reverse

535

536

537

538

539

540

541

542

543

544

545

546

547

548

549

550

551

552

553

554

555

556

557

558

559

560

561

562

563

564

565

566

567

568

569

570

571

572

573

574

575

576

577

578

579

580

581

582

583

transcription-PCR data: a model-based variance estimation approach to identify genes suited for normalization, applied to bladder and colon cancer data sets. Cancer research 64:5245-5250.

Axtner J, and Sommer S. 2009. Validation of internal reference genes for quantitative real-time PCR in a non-model organism, the yellow-necked mouse, Apodemus flavicollis. BMC research notes 2:264.

Badisco L, Ott SR, Rogers SM, Matheson T, Knapen D, Vergauwen L, Verlinden H, Marchal E, Sheehy MR, and Burrows M. 2011. Microarray-based transcriptomic analysis of differences between long-term gregarious and solitarious desert locusts. PloS one 6:e28110.

Barrientos Lozano L, Astacio Cabrera L, Alvarez Bonilla O, and Poot Martínez F. 1992. Manual técnico sobre la langosta voladora (Schistocerca piceifrons piceifrons Walker, 1870) y otros Acridoideos de Centro América y Sureste de México. Food and Agriculture Organization (FAO), San Salvador (El Salvador)/Organismo Internacional Regional de Sanidad Agropecuaria (OIRSA), San Salvador (El Salvador).

Blankenberg D, Gordon A, Von Kuster G, Coraor N, Taylor J, Nekrutenko A, and Galaxy Team. 2010. Manipulation of FASTQ data with Galaxy. Bioinformatics 26:1783-1785.

Bolger AM, Lohse M, and Usadel B. 2014. Trimmomatic: a flexible trimmer for Illumina sequence data. Bioinformatics 30:2114-2120.

Bonnet M, Bernard L, Bes S, and Leroux C. 2013. Selection of reference genes for quantitative real-time PCR normalisation in adipose tissue, muscle, liver and mammary gland from ruminants. Animal 7:13441353.

Bredo H. 1963. Rapport de mission relatif a l'etude du Schistocerca paranensis Burm. en Amerique Centrale, Panama et Mexique. Food and Agriculture Organization (FAO), Rome (Italy).

Breugelmans B, Simonet G, Van Hoef V, Claeys I, Van Soest S, and Vanden Broeck J. 2008.

Quantitative RT-PCR analysis of pacifastin-related precursor transcripts during the reproductive cycle of solitarious and gregarious desert locusts. Insect molecular biology 17:137-145.

Breugelmans B, Simonet G, van Hoef V, Van Soest S, and Vanden Broeck J. 2009. Pacifastin-related peptides: structural and functional characteristics of a family of serine peptidase inhibitors. Peptides 30:622-632.

Bustin SA, Benes V, Garson J, Hellemans J, Huggett J, Kubista M, Mueller R, Nolan T, Pfaffl MW, and Shipley G. 2013. The need for transparency and good practices in the qPCR literature. Nature methods 10:1063-1067.

Bustin SA, Benes V, Garson JA, Hellemans J, Huggett J, Kubista M, Mueller R, Nolan T, Pfaffl MW, and Shipley GL. 2009. The MIQE Guidelines: Minimum Information for Publication of $Q$ uantitative RealTime PCR Experiments. Clinical Chemistry 55:611-622.

Chapuis M-P, Tohidi-Esfahani D, Dodgson T, Blondin L, Ponton F, Cullen D, Simpson SJ, and Sword GA. 2011. Assessment and validation of a suite of reverse transcription-quantitative PCR reference genes for analyses of density-dependent behavioural plasticity in the Australian plague locust. BMC molecular biology 12:7.

Chen D, Pan X, Xiao P, Farwell MA, and Zhang B. 2011. Evaluation and identification of reliable reference genes for pharmacogenomics, toxicogenomics, and small RNA expression analysis. Journal of cellular physiology 226:2469-2477.

Chen G, Zhao L, Feng J, You G, Sun Q, Li P, Han D, and Zhou H. 2013. Validation of reliable reference genes for real-time PCR in human umbilical vein endothelial cells on substrates with different stiffness. PloS one 8.

Cullen DA, Cease AJ, Latchininsky AV, Ayali A, Berry K, Buhl J, De Keyser R, Foquet B, Hadrich JC, Matheson T, Ott SR, Poot-Pech MA, Robinson BE, Smith JM, Song H, Sword GA, Vanden Broeck J, Verdonck R, Verlinden H, and Rogers SM. 2017. From Molecules to Management: Mechanisms and Consequences of Locust Phase Polyphenism. Advances in Insect Physiology 53:167-285.

Dheda K, Huggett JF, Bustin SA, Johnson MA, Rook G, and Zumla A. 2004. Validation of housekeeping genes for normalizing RNA expression in real-time PCR. Biotechniques 37:112-119.

Peer] reviewing PDF | (2020:05:49192:1:1:NEW 24 Jun 2020) 
584 Edgar RC. 2004. MUSCLE: multiple sequence alignment with high accuracy and high throughput.

585 Nucleic acids research 32:1792-1797.

586 Eisenberg E, and Levanon EY. 2013. Human housekeeping genes, revisited. TRENDS in Genetics

587 29:569-574.

588 Escobar MD, and Hunt JL. 2017. A cost-effective RNA extraction technique from animal cells and tissue using silica columns. Journal of biological methods 4. Fu L, Niu B, Zhu Z, Wu S, and Li W. 2012. CDHIT: accelerated for clustering the next-generation sequencing data. Bioinformatics 28:3150-3152. Gachon C, Mingam A, and Charrier B. 2004. Real-time PCR: what relevance to plant studies? Journal of experimental botany 55:1445-1454.

Giménez MJ, Pistón F, and Atienza SG. 2011. Identification of suitable reference genes for normalization of qPCR data in comparative transcriptomics analyses in the Triticeae. Planta 233:163-173. reference genes for RT-qPCR studies in three metabolism related tissues of mice after caloric restriction.

597 Scientific reports 6:1-12.

598 Gotham S, and Song H. 2013. Non-swarming grasshoppers exhibit density-dependent phenotypic

599 plasticity reminiscent of swarming locusts. Journal of Insect Physiology 59:1151-1159.

600 Grabherr MG, Haas BJ, Yassour M, Levin JZ, Thompson DA, Amit I, Adiconis X, Fan L, Raychowdhury

601 R, and Zeng Q. 2011. Full-length transcriptome assembly from RNA-Seq data without a reference

602 genome. Nature biotechnology 29:644-652.

603 Gutierrez L, Mauriat M, Guénin S, Pelloux J, Lefebvre JF, Louvet R, Rusterucci C, Moritz T, Guerineau

604 F, and Bellini C. 2008. The lack of a systematic validation of reference genes: a serious pitfall

605

606 undervalued in reverse transcription-polymerase chain reaction (RT-PCR) analysis in plants. Plant

biotechnology journal 6:609-618

607 Harvey A. 1983. Schistocerca piceifrons (Walker)(Orthoptera: Acrididae), the swarming locust of tropical

608

609

610

611

612 Johnson M, Zaretskaya I, Raytselis Y, Merezhuk Y, McGinnis S, and Madden TL. 2008. NCBI BLAST:

613 a better web interface. Nucleic acids research 36:W5-W9.

614 Kataoka H, Toschi A, Li JP, Carney RL, Schooley DA, and Kramer SJ. 1989. Identification of an

615 allatotropin from adult Manduca sexta. Science 243:1481-1483.

616 Koressaar T, and Remm M. 2007. Enhancements and modifications of primer design program Primer3.

617 Bioinformatics 23:1289-1291.

618 Kozera B, and Rapacz M. 2013. Reference genes in real-time PCR. Journal of applied genetics 54:391-

619406.

620 Langmead B, and Salzberg SL. 2012. Fast gapped-read alignment with Bowtie 2. Nature methods 9:357-

621359.

622 Langmead B, Trapnell C, Pop M, and Salzberg SL. 2009. Ultrafast and memory-efficient alignment of

623

624 short DNA sequences to the human genome. Genome biology 10:R25.

625

626

627 Li H. 2011a. Improving SNP discovery by base alignment quality. Bioinformatics 27:1157-1158.

Li H. 2011b. A statistical framework for SNP calling, mutation discovery, association mapping and population genetical parameter estimation from sequencing data. Bioinformatics 27:2987-2993.

Li H, Handsaker B, Wysoker A, Fennell T, Ruan J, Homer N, Marth G, Abecasis G, and Durbin R. 2009. The sequence alignment/map format and SAMtools. Bioinformatics 25:2078-2079.

$629 \mathrm{Li} \mathrm{W}$, and Godzik A. 2006. Cd-hit: a fast program for clustering and comparing large sets of protein or 630 nucleotide sequences. Bioinformatics 22:1658-1659.

631 Lin L, Liu S, Brockway H, Seok J, Jiang P, Wong WH, and Xing Y. 2009. Using high-density exon 632 arrays to profile gene expression in closely related species. Nucleic acids research 37:e90. 
633 Lismont E, Vleugels R, Marchal E, Badisco L, Van Wielendaele P, Lenaerts C, Zels S, Tobe SS, Vanden

634 Broeck J, and Verlinden H. 2015. Molecular cloning and characterization of the allatotropin precursor and

635 receptor in the desert locust, Schistocerca gregaria. Frontiers in neuroscience 9:84.

636 Livak KJ, and Schmittgen TD. 2001. Analysis of relative gene expression data using real-time

637 quantitative PCR and the $2^{-\Delta \Delta \mathrm{C}}$ Tethod. methods 25:402-408.

638 Love MI, Huber W, and Anders S. 2014. Moderated estimation of fold change and dispersion for RNA-

639 seq data with DESeq2. Genome biology 15:550.

640 Lü J, Yang C, Zhang Y, and Pan H. 2018. Selection of reference genes for the normalization of RT-qPCR

641 data in gene expression studies in insects: a systematic review. Frontiers in physiology 9:1560.

642 Macharia RW, Ombura FL, and Aroko EO. 2015. Insects' RNA profiling reveals absence of "hidden

643 break" in 28S ribosomal RNA molecule of onion thrips, Thrips tabaci. Journal of nucleic acids 2015.

644 Mestdagh P, Van Vlierberghe P, De Weer A, Muth D, Westermann F, Speleman F, and Vandesompele J.

645 2009. A novel and universal method for microRNA RT-qPCR data normalization. Genome biology

646 10:R64.

647 Nicot N, Hausman J-F, Hoffmann L, and Evers D. 2005. Housekeeping gene selection for real-time RT-

648 PCR normalization in potato during biotic and abiotic stress. Journal of experimental botany 56:2907-

6492914.

650 Pener M. 1983. Endocrine aspects of phase polymorphism in locusts. Invertebrate Endocrinology 1:379-

651394.

652 Pener MP, and Simpson SJ. 2009. Locust phase polyphenism: an update. Advances in Insect Physiology

653 36:1-272.

654 Pereira-Fantini PM, Rajapaksa AE, Oakley R, and Tingay DG. 2016. Selection of reference genes for

655

656 gene expression studies related to lung injury in a preterm lamb model. Scientific reports 6:26476.

657 Pfaffl MW, Tichopad A, Prgomet C, and Neuvians TP. 2004. Determination of stable housekeeping

658 genes, differentially regulated target genes and sample integrity: BestKeeper-Excel-based tool using pairwise correlations. Biotechnology letters 26:509-515.

659 R Core Team. 2017. R: A language and environment for statistical computing. R Foundation for

660 Statistical Computing, Vienna, Austria, http://www.R-project.org/.

661 Salazar-Jaramillo L, Jalvingh KM, de Haan A, Kraaijeveld K, Buermans H, and Wertheim B. 2017. Inter662 and intra-species variation in genome-wide gene expression of Drosophila in response to parasitoid wasp 663 attack. BMC genomics 18:331.

664 Simão FA, Waterhouse RM, Ioannidis P, Kriventseva EV, and Zdobnov EM. 2015. BUSCO: assessing

665 genome assembly and annotation completeness with single-copy orthologs. Bioinformatics 31:3210-3212.

666 Simonet G, Breugelmans B, Proost P, Claeys I, Van Damme J, Arnold D, and Vanden Broeck J. 2005.

667 Characterization of two novel pacifastin-like peptide precursor isoforms in the desert locust (Schistocerca

668 gregaria): cDNA cloning, functional analysis and real-time RT-PCR gene expression studies.

669 Biochemical Journal 388:281-289.

670 Simonet G, Claeys I, Breugelmans B, Van Soest S, De Loof A, and Vanden Broeck J. 2004. Transcript

671

672 profiling of pacifastin-like peptide precursors in crowd-and isolated-reared desert locusts. Biochemical and biophysical research communications 317:565-569.

673 Smith-Unna R, Boursnell C, Patro R, Hibberd JM, and Kelly S. 2016. TransRate: reference-free quality

674 assessment of de novo transcriptome assemblies. Genome research 26:1134-1144.

Song H, Foquet B, Mariño-Pérez R, and Woller DA. 2017. Phylogeny of locusts and grasshoppers reveals complex evolution of density-dependent phenotypic plasticity. Scientific reports 7:6606.

677 Sørensen JG, Giribets MP, Tarrío R, Rodríguez-Trelles F, Schou MF, and Loeschcke V. 2019. Expression

678 of thermal tolerance genes in two Drosophila species with different acclimation capacities. Journal of

679 thermal biology 84:200-207.

680 Stay B, Tobe SS, and Bendena WG. 1995. Allatostatins: identification, primary structures, functions and 681 distribution. Advances in Insect Physiology: Elsevier, 267-337.

682 Thellin O, ElMoualij B, Heinen E, and Zorzi W. 2009. A decade of improvements in quantification of

683 gene expression and internal standard selection. Biotechnology advances 27:323-333. 
684 Tricarico C, Pinzani P, Bianchi S, Paglierani M, Distante V, Pazzagli M, Bustin SA, and Orlando C.

685 2002. Quantitative real-time reverse transcription polymerase chain reaction: normalization to rRNA or

686 single housekeeping genes is inappropriate for human tissue biopsies. Analytical biochemistry 309:293-

687300.

688 Untergasser A, Cutcutache I, Koressaar T, Ye J, Faircloth BC, Remm M, and Rozen SG. 2012. Primer3-

689 new capabilities and interfaces. Nucleic acids research 40:e115.

690 Uvarov B. 1921. A revision of the genus Locusta, L.(= Pachytylus, Fieb.), with a new theory as to the

691 periodicity and migrations of locusts. Bulletin of entomological Research 12:135-163.

692 Van Hiel MB, Van Wielendaele P, Temmerman L, Van Soest S, Vuerinckx K, Huybrechts R, Vanden

693 Broeck J, and Simonet G. 2009. Identification and validation of housekeeping genes in brains of the

694 desert locust Schistocerca gregaria under different developmental conditions. BMC molecular biology

$69510: 56$.

696 Vandesompele J, De Preter K, Pattyn F, Poppe B, Van Roy N, De Paepe A, and Speleman F. 2002.

697 Accurate normalization of real-time quantitative RT-PCR data by geometric averaging of multiple

698 internal control genes. Genome biology 3:research0034.1.

699 Varet H, Brillet-Guéguen L, Coppée J-Y, and Dillies M-A. 2016. SARTools: a DESeq2-and edgeR-based

700 R pipeline for comprehensive differential analysis of RNA-Seq data. PloS one 11:e0157022.

701 Verlinden H, Badisco L, Marchal E, Van Wielendaele P, and Vanden Broeck J. 2009. Endocrinology of

702 reproduction and phase transition in locusts. General and comparative endocrinology 162:79-92.

703 Wang H, Foquet B, Dewell RB, Song H, Dierick HA, and Gabbiani F. 2020. Molecular characterization

704 and distribution of the voltage-gated sodium channel, Para, in the brain of the grasshopper and vinegar

705 fly. Journal of Comparative Physiology A:1-19.

706 Weyrich A, Axtner J, and Sommer S. 2010. Selection and validation of reference genes for real-time RT-

707 PCR studies in the non-model species Delomys sublineatus, an endemic Brazilian rodent. Biochemical

708 and biophysical research communications 392:145-149.

709 Wingett SW, and Andrews S. 2018. FastQ Screen: A tool for multi-genome mapping and quality control.

710 F1000Research 7:1338.

711 Winnebeck EC, Millar CD, and Warman GR. 2010. Why does insect RNA look degraded? Journal of

712 Insect Science 10:159.

713 Wittkopp PJ, Vaccaro K, and Carroll SB. 2002. Evolution of yellow gene regulation and pigmentation in

714 Drosophila. Current Biology 12:1547-1556.

715 Yang Q, Li Z, Cao J, Zhang S, Zhang H, Wu X, Zhang Q, and Liu X. 2014. Selection and assessment of

716 reference genes for quantitative PCR normalization in migratory locust Locusta migratoria (Orthoptera:

717 Acrididae). PloS one 9:e98164.

718

719

720

Peer] reviewing PDF | (2020:05:49192:1:1:NEW 24 Jun 2020) 


\section{Figure 1}

Mean $C_{T}$ values of reference genes for qPCR study.

$\mathrm{C}_{\mathrm{T}}$ values were obtained by qPCR for all tested reference genes for all tissue, rearing condition and species combinations. Boxes and error bars represent the mean \pm standard error of mean of $C_{T}$ values. Each group contained five biological replicates. Graphs represent observations for A. piceifrons, B. americana, C. cubense and D. nitens.

A 30

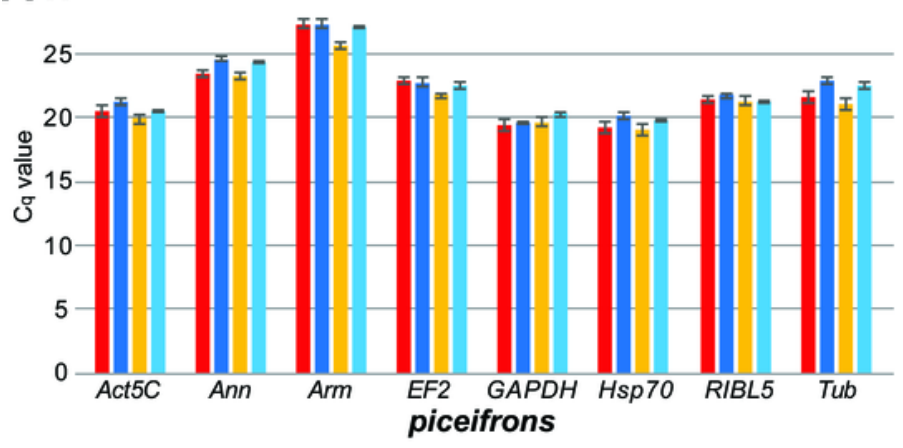

$\mathbf{C}_{30}$

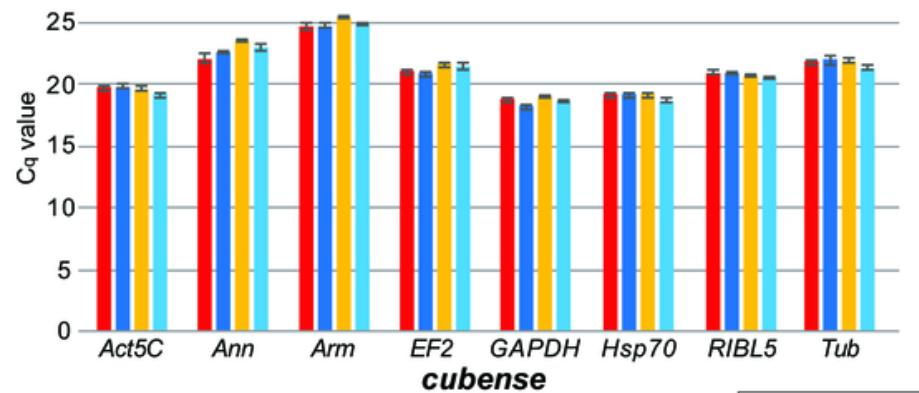

$\mathbf{B}_{30}$

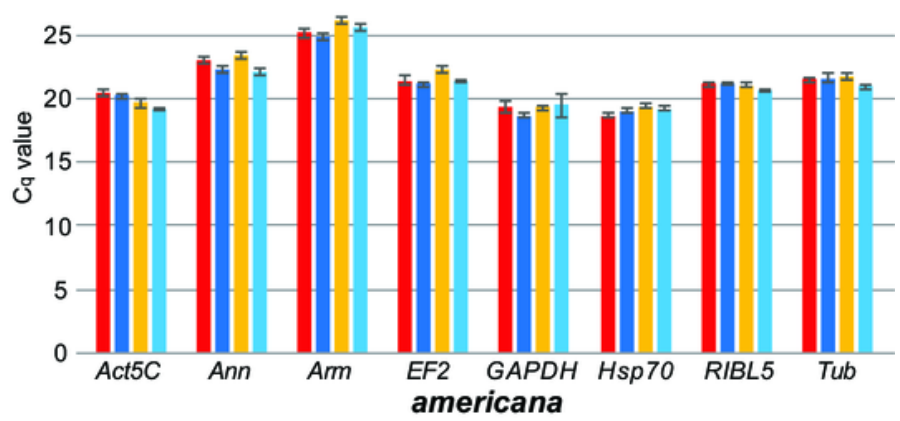

D 30

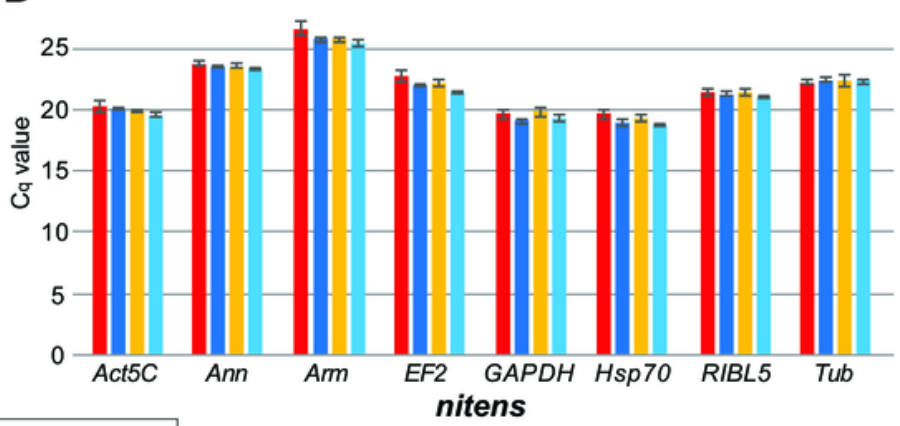

nead tissue, crowded-reared

head tissue, isolated-reared

thorax tissue, crowded-reared

inorax tissue, isolated-reared 


\section{Figure 2}

Pairwise variation analysis for qPCR reference genes.

All data were generated in qbase+ using the GeNorm algorithm, based on five biological replicates per group. Values represent the pairwise variation analysis between normalization factors $\mathrm{NF}_{\mathrm{n}}$ and $\mathrm{NF}_{\mathrm{n+1}}$, or the decrease in variation when adding an additional reference gene. Using 0.15 as a threshold, the optimal number of reference genes required for accurate normalization can be determined. Graphs are shown for A. head and B. thorax tissues for each species. 

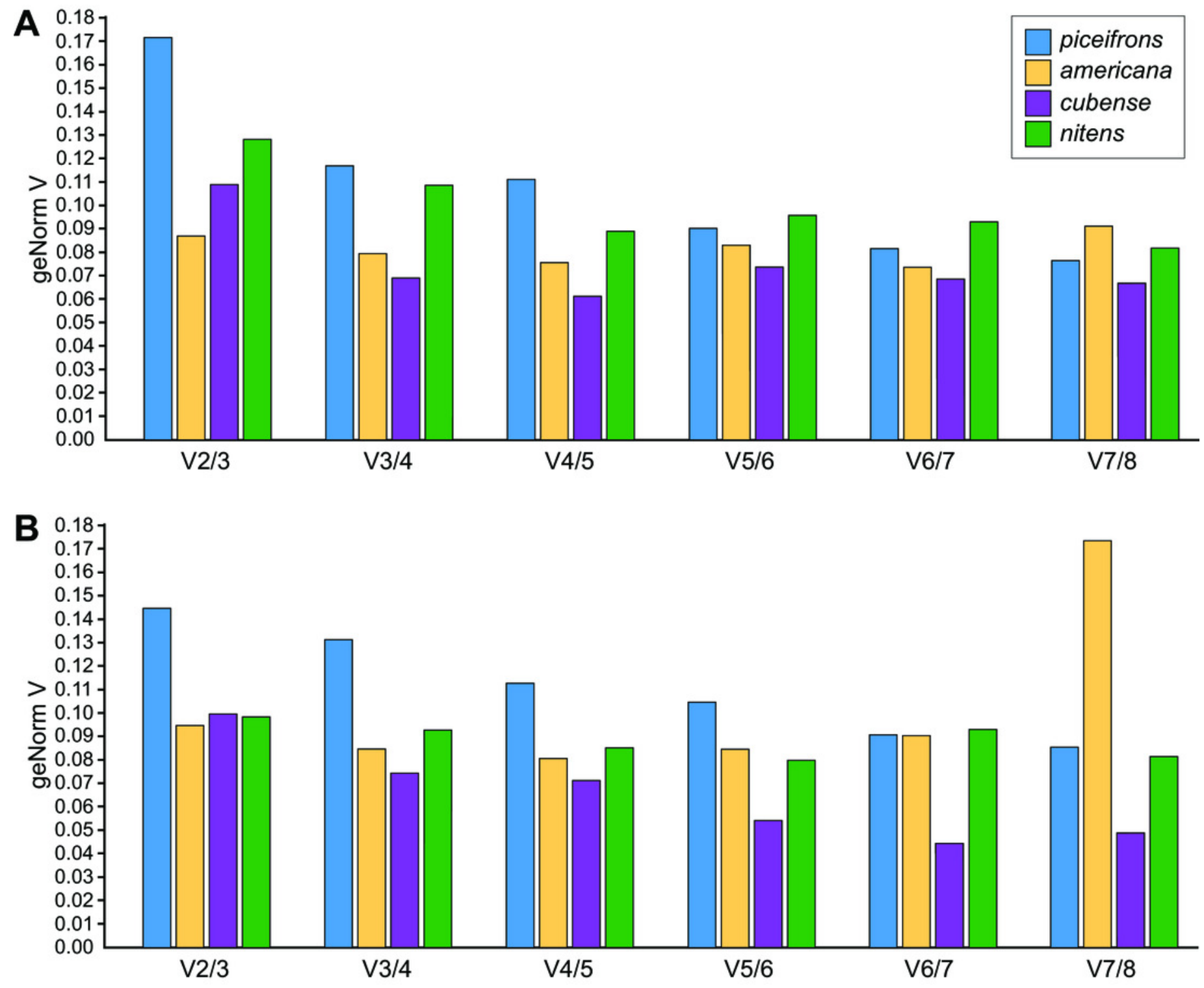


\section{Figure 3}

Influence of selected reference genes on target gene expression in qPCR.

Relative concentrations were calculated with the $\Delta \Delta \mathrm{C}_{\mathrm{T}}$-method, with values shown in the graph representing the exponentialized values. Error bars represent the standard error of mean, calculated on exponentialized values. $\mathrm{p}$-values were calculated based on the $\Delta \mathrm{C}_{\mathrm{T}}$ values. All data is based on the expression in five isolated-reared and five crowded-reared individuals. Significant differences between isolated-reared and crowded-reared individuals were marked for $p<0.05(*)$ or $p<0.01(* *)$.A. all available reference genes were used; Act5C, Ann, Arm, Hsp70, EF2, GAPDH and RIBL5, B. only suggested reference genes were used; RIBL5, GAPDH and Hsp70, C. All reference genes showing a trend towards differential expression in thorax were used; every reference gene except RIBL5.
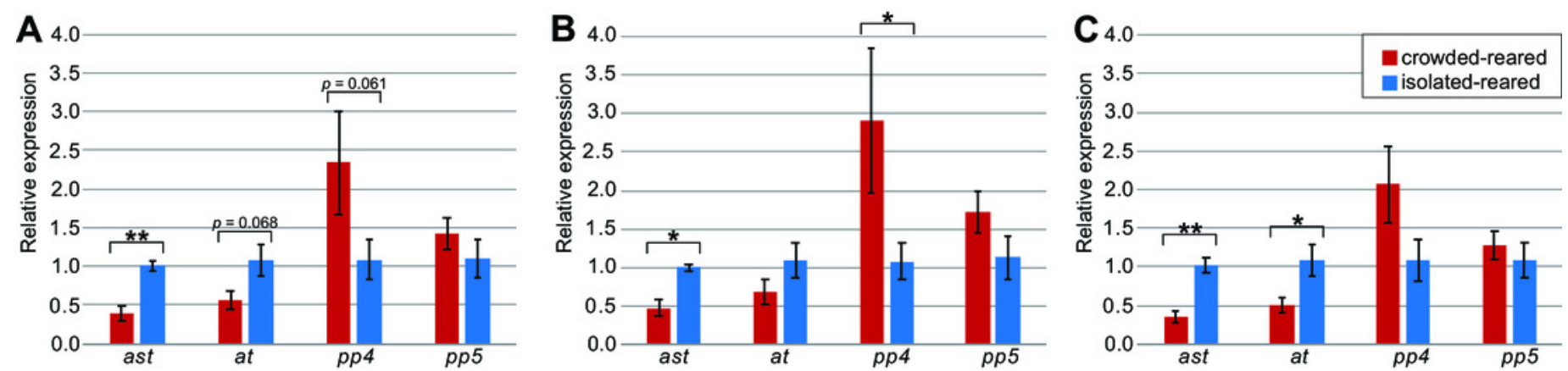


\section{Table 1 (on next page)}

Reference genes and target genes used in this study and their known functions, with Genbank accession numbers. 
1 Table 1:

2 Reference genes and target genes used in this study and their known functions, with 3 Genbank accession numbers.

\begin{tabular}{|c|c|c|c|c|c|c|}
\hline \multirow[b]{2}{*}{ Gene } & \multirow[b]{2}{*}{ Full name } & \multicolumn{4}{|c|}{ Associated Genbank accession number } & \multirow[b]{2}{*}{ Function } \\
\hline & & piceifrons & americana & cubense & nitens & \\
\hline Act5C & Actin $5 C$ & MT498271 & MT498272 & MT498273 & MT498274 & $\begin{array}{l}\text { Structural } \\
\text { constituent of } \\
\text { cytoskeleton }\end{array}$ \\
\hline Tub & Tubulin & MT498316 & MT498313 & MT498314 & MT498315 & $\begin{array}{l}\text { Structural } \\
\text { constituent of } \\
\text { cytoskeleton }\end{array}$ \\
\hline Hsp70 & $\begin{array}{l}\text { Heat shock } \\
\text { protein } 70\end{array}$ & MT498304 & MT498301 & MT498302 & MT498303 & $\begin{array}{l}\text { Stress response, } \\
\text { protein folding }\end{array}$ \\
\hline RIBL5 & $\begin{array}{l}\text { Ribosomal } \\
\text { protein L5 }\end{array}$ & MT498312 & MT498310 & MT498311 & MT498309 & $\begin{array}{l}\text { Structural } \\
\text { component of } \\
\text { ribosome, } \\
\text { protein translation }\end{array}$ \\
\hline$E F 2$ & $\begin{array}{l}\text { Elongation } \\
\text { factor } 2\end{array}$ & MT498294 & MT498295 & MT498296 & MT498293 & Protein synthesis \\
\hline GAPDH & $\begin{array}{l}\text { Glyceraldehyde } \\
\text { phosphate } \\
\text { dehydrogenase }\end{array}$ & MT498297 & MT498299 & MT498300 & MT498298 & $\begin{array}{l}\text { Oxidoreductase in } \\
\text { glycolysis \& } \\
\text { gluconeogenesis }\end{array}$ \\
\hline Ann & Annexin IX & MT498288 & MT498285 & MT498286 & MT498287 & $\begin{array}{l}\text { Formation of } \\
\text { membrane } \\
\text { scaffolds, actin } \\
\text { binding }\end{array}$ \\
\hline Arm & Armadillo & MT498292 & MT498289 & MT498290 & MT498291 & $\begin{array}{l}\text { Wnt signal } \\
\text { transduction } \\
\text { pathway }\end{array}$ \\
\hline ast & allatostatin & MT498275 & & & & $\begin{array}{l}\text { Pleiotropic } \\
\text { neuropeptide, } \\
\text { downregulation of } \\
\text { JH production }\end{array}$ \\
\hline at & allatotropin & MT498280 & & & & $\begin{array}{l}\text { Pleiotropic } \\
\text { neuropeptide, } \\
\text { upregulation of } \mathrm{JH} \\
\text { production }\end{array}$ \\
\hline$S P P P-4$ & $\begin{array}{l}\text { pacifastin- } \\
\text { related peptide } 4\end{array}$ & MT498307 & & & & peptidase inhibitor \\
\hline SPPP-5 & $\begin{array}{l}\text { pacifastin- } \\
\text { related peptide } 5\end{array}$ & MT498308 & & & & peptidase inhibitor \\
\hline
\end{tabular}

4 


\section{Table 2 (on next page)}

Primer information for qPCR experiment.

Primer sequences, amplicon melt temperature and primer efficiencies are given. Primer efficiencies were obtained with a 10 -fold dilution series ranging from $1 / 1$ to $1 / 1,000,000$. 


\section{Table 2:}

2 Primer information for qPCR experiment.

3 Primer sequences, amplicon melt temperature and primer efficiencies are given. Primer

4 efficiencies were obtained with either a 10-fold dilution series ranging from $1 / 1$ to $1 / 10,000$ or a

5 5-fold dilution series ranging from $1 / 1$ to $1 / 3,125$.

\begin{tabular}{|c|c|c|c|c|c|c|c|c|c|}
\hline \multirow[b]{2}{*}{$\begin{array}{l}\text { Gene } \\
\text { code }\end{array}$} & \multirow[b]{2}{*}{ Primer sequences } & \multicolumn{2}{|c|}{ piceifrons } & \multicolumn{2}{|c|}{ americana } & \multicolumn{2}{|c|}{ cubense } & \multicolumn{2}{|c|}{ nitens } \\
\hline & & $\begin{array}{l}\operatorname{Tm} \\
\left({ }^{\circ} \mathrm{C}\right)\end{array}$ & $\begin{array}{l}E \\
(\%)\end{array}$ & $\begin{array}{l}\operatorname{Tm} \\
\left({ }^{\circ} \mathrm{C}\right)\end{array}$ & $\begin{array}{l}E \\
(\%)\end{array}$ & $\begin{array}{l}\mathrm{Tm} \\
\left({ }^{\circ} \mathrm{C}\right)\end{array}$ & $\begin{array}{c}E \\
(\%)\end{array}$ & $\begin{array}{l}\operatorname{Tm} \\
\left({ }^{\circ} \mathrm{C}\right)\end{array}$ & $\begin{array}{c}E \\
(\%)\end{array}$ \\
\hline Act5C & $\begin{array}{l}\text { F: AACTTTCAACACCCCAGCCA } \\
\text { R: AACGCCATCACCAGAATCCA }\end{array}$ & 82.5 & 102.13 & 82.5 & 105.84 & 82.3 & 97.65 & 82.0 & 104.21 \\
\hline Tub & $\begin{array}{l}\text { F: AGCTCATCACTGGCAAGGAG } \\
\text { R: TCCTGATGCGATCCAACACC }\end{array}$ & 81.5 & 103.15 & 81.5 & 100.30 & 81.5 & 104.90 & 82.0 & 96.18 \\
\hline Hsp70 & $\begin{array}{l}\text { F: TCGTCAACTCAAGCCAGCAT } \\
\text { R: TGCTTTCTCCACAGGTTCCA }\end{array}$ & 80.5 & 100.18 & 80.3 & 105.06 & 80.3 & 102.16 & 80.0 & 104.14 \\
\hline RIBL5 & $\begin{array}{l}\text { F: TCGGCTGCACAGAAGTTACC } \\
\text { R: AGCTCCAGTAGTTGTGCGGA }\end{array}$ & 83.7 & 99.83 & 83.7 & 101.20 & 83.5 & 96.78 & 84.0 & 102.11 \\
\hline$E F 2$ & $\begin{array}{l}\text { F: CATCTCCTGTGGTTGCACAG } \\
\text { R: ATGACACCAACTGCTGCTTC }\end{array}$ & 79.3 & 100.00 & 79.0 & 102.73 & 79.3 & 101.33 & 79.3 & 98.98 \\
\hline GAPDH & $\begin{array}{l}\text { F: TGGCTTTCAGAGTCCCAGTG } \\
\text { R: AGCAGCTTCCTTCACCTTGG }\end{array}$ & 84.0 & 102.28 & 84.0 & 97.74 & 83.7 & 98.57 & 83.3 & 98.53 \\
\hline Ann & $\begin{array}{l}\text { F: ATAGGGGAATTGTGCAGCGG } \\
\text { R: TGCCACTCAGTTCACTCTTC }\end{array}$ & 79.7 & 100.10 & 79.7 & 102.39 & 79.5 & 99.47 & 79.5 & 104.14 \\
\hline Arm & $\begin{array}{l}\text { F: TCTCAGAGAGTTCGTGCTGC } \\
\text { R: GGCTTGGTTCTGCTAGACGT }\end{array}$ & 82.3 & 109.85 & 82.7 & 101.41 & 82.5 & 99.27 & 82.5 & 92.12 \\
\hline ast & $\begin{array}{l}\text { F: TCAACCAAACCCGCCTCAAG } \\
\text { R: ACACTACCCCACAGAGAAGC }\end{array}$ & 81.3 & 96.84 & & & & & & \\
\hline at & $\begin{array}{l}\text { F: GATGCAGAACAACCCGGAAC } \\
\text { R: CAGTAAGTGGGCCTGAGGAG }\end{array}$ & 85.0 & 91.26 & & & & & & \\
\hline SPPP-4 & $\begin{array}{l}\text { F: ACTCCAGGAACCATGAAGAAGG } \\
\text { R: AGGAGTGCAGTTTACCTCTCTC }\end{array}$ & 83.5 & 91.19 & & & & & & \\
\hline SPPP-5 & $\begin{array}{l}\text { F: AGCTGTACACCCAACTCGAC } \\
\text { R: TCGTTCCAGGAGTGCAGTTC }\end{array}$ & 87.0 & 94.51 & & & & & & \\
\hline
\end{tabular}

20 Tm: melt temperature of the PCR amplicon. E: primer efficiency. 


\section{Table 3 (on next page)}

Fold changes of reference genes in piceifrons obtained from RNA-Seq experiment.

Fold changes were calculated by Deseq2 in SARTools. The isolated-reared condition was taken as reference. Five isolated-reared and five crowded-reared last instar nymphs were used. Adjusted $p$-values were obtained using default settings. 
1 Table 3:

2 Fold changes of reference genes in piceifrons obtained from RNA-Seq experiment.

3 Fold changes were calculated by Deseq2 in SARTools. The isolated-reared condition was taken 4 as reference. Five isolated-reared and five crowded-reared last instar nymphs were used.

5 Adjusted $p$-values were obtained using default settings.

\begin{tabular}{|l|c|c|c|c|}
\hline \multirow{2}{*}{ Gene } & \multicolumn{3}{|c|}{ Head } & \multicolumn{2}{c|}{ Thorax } \\
\cline { 2 - 5 } & Fold change & Adjusted $p$-value & Fold change & Adjusted $p$-value \\
\hline Act5c & 1.255 & 0.865 & 1.602 & 0.037 \\
\hline Ann & 1.420 & 0.815 & 1.654 & 0.033 \\
\hline Arm & 1.081 & 0.973 & 1.270 & 0.293 \\
\hline EF2 & 0.983 & 0.997 & 1.189 & 0.598 \\
\hline GAPDH & 1.050 & 0.988 & 0.995 & 0.993 \\
\hline Hsp70 & 0.966 & 0.993 & 1.201 & 0.501 \\
\hline RIBL5 & 0.910 & 0.972 & 1.134 & 0.796 \\
\hline Tub & 0.878 & 0.954 & 0.897 & 0.832 \\
\hline
\end{tabular}




\section{Table 4 (on next page)}

Stability values for reference genes in piceifrons and americana.

Stability values for eight reference genes were obtained using three different algorithms: geNorm, NormFinder and BestKeeper. Stability values and ranking from most stable to least stable are given for each gene. A comprehensive ranking was calculated by taking the geometric mean of rankings obtained by the different algorithms. Head and thorax tissue were investigated separately. For each group, five isolated-reared and five crowded-reared last instar nymphs were used. 
1 Table 4:

2 Stability values for reference genes in piceifrons and americana.

3 Stability values for eight reference genes were obtained using three different algorithms:

4 geNorm, NormFinder and BestKeeper. Stability values and ranking from most stable to least

5 stable are given for each gene. A comprehensive ranking was calculated by taking the

6 geometric mean of rankings obtained by the different algorithms. Head and thorax tissue were

7 investigated separately. For each group, five isolated-reared and five crowded-reared last instar

8 nymphs were used.

\begin{tabular}{|c|c|c|c|c|c|c|c|c|c|}
\hline \multirow[t]{2}{*}{ Species/Tissue } & \multirow[t]{2}{*}{ Gene } & \multicolumn{2}{|c|}{ geNorm } & \multicolumn{2}{|c|}{ NormFinder } & \multicolumn{3}{|c|}{ BestKeeper } & \multirow{2}{*}{$\begin{array}{c}\text { Comprehensive } \\
\text { ranking }\end{array}$} \\
\hline & & Rank & M & Rank & $\begin{array}{l}\text { Stability } \\
\text { value }\end{array}$ & Rank & $\begin{array}{l}\text { std. } \\
\text { dev. }\end{array}$ & $\mathbf{r}$ & \\
\hline \multirow{8}{*}{ piceifrons head } & Act5C & 1 & 0.506 & 1 & 0.117 & 1 & 0.630 & 0.993 & 1 \\
\hline & Ann & 3 & 0.579 & 3 & 0.265 & 5 & 0.576 & 0.894 & 3 \\
\hline & Arm & 6 & 0.669 & 7 & 0.341 & 7 & 0.581 & 0.742 & 8 \\
\hline & EF2 & 4 & 0.648 & 6 & 0.333 & 6 & 0.597 & 0.761 & 6 \\
\hline & GAPDH & 7 & 0.706 & 5 & 0.303 & 8 & 0.463 & 0.725 & 7 \\
\hline & Hsp70 & 5 & 0.668 & 4 & 0.295 & 4 & 0.710 & 0.895 & 4 \\
\hline & RIBL5 & 2 & 0.562 & 2 & 0.207 & 3 & 0.427 & 0.911 & 2 \\
\hline & Tub & 8 & 0.719 & 8 & 0.375 & 2 & 0.855 & 0.931 & 5 \\
\hline \multirow{8}{*}{ piceifrons thorax } & Act5C & 2 & 0.560 & 2 & 0.148 & 4 & 0.533 & 0.925 & 2 \\
\hline & Ann & 1 & 0.500 & 1 & 0.131 & 1 & 0.615 & 0.972 & 1 \\
\hline & Arm & 3 & 0.592 & 4 & 0.241 & 2 & 0.747 & 0.941 & 3 \\
\hline & $E F 2$ & 4 & 0.671 & 5 & 0.251 & 7 & 0.444 & 0.676 & 5 \\
\hline & GAPDH & 6 & 0.749 & 6 & 0.262 & 6 & 0.527 & 0.694 & 7 \\
\hline & Hsp70 & 5 & 0.720 & 3 & 0.219 & 5 & 0.696 & 0.851 & 4 \\
\hline & RIBL5 & 8 & 0.782 & 8 & 0.405 & 8 & 0.337 & 0.477 & 8 \\
\hline & Tub & 7 & 0.757 & 7 & 0.344 & 3 & 0.865 & 0.937 & 6 \\
\hline \multirow{8}{*}{ americana head } & Act5C & 1 & 0.402 & 1 & 0.053 & 1 & 0.383 & 0.944 & 1 \\
\hline & Ann & 5 & 0.525 & 6 & 0.223 & 3 & 0.499 & 0.868 & 5 \\
\hline & Arm & 4 & 0.497 & 4 & 0.166 & 2 & 0.525 & 0.906 & 3 \\
\hline & EF2 & 2 & 0.450 & 2 & 0.136 & 4 & 0.438 & 0.856 & 2 \\
\hline & GAPDH & 8 & 0.788 & 8 & 0.280 & 7 & 0.569 & 0.556 & 8 \\
\hline & Hsp70 & 6 & 0.579 & 7 & 0.263 & 8 & 0.328 & 0.553 & 7 \\
\hline & RIBL5 & 3 & 0.456 & 3 & 0.158 & 5 & 0.289 & 0.826 & 4 \\
\hline & Tub & 7 & 0.613 & 5 & 0.223 & 6 & 0.411 & 0.715 & 6 \\
\hline \multirow{8}{*}{ americana thorax } & Act5C & 2 & 0.578 & 3 & 0.174 & 4 & 0.358 & 0.820 & 4 \\
\hline & Ann & 7 & 0.799 & 7 & 0.250 & 5 & 0.679 & 0.784 & 7 \\
\hline & Arm & 4 & 0.627 & 2 & 0.111 & 2 & 0.559 & 0.850 & 3 \\
\hline & EF2 & 3 & 0.601 & 4 & 0.176 & 1 & 0.485 & 0.853 & 2 \\
\hline & GAPDH & 8 & 1.435 & 8 & 0.432 & 8 & 0.855 & 0.416 & 8 \\
\hline & Hsp70 & 5 & 0.634 & 6 & 0.189 & 7 & 0.287 & 0.522 & 6 \\
\hline & RIBL5 & 1 & 0.548 & 1 & 0.098 & 3 & 0.284 & 0.837 & 1 \\
\hline & Tub & 6 & 0.712 & 5 & 0.182 & 6 & 0.566 & 0.700 & 5 \\
\hline
\end{tabular}

9 M: stability value calculated by geNorm. Std. dev.: standard deviation on $\mathrm{C}_{\mathrm{T}}$ values of reference gene. r: correlation coefficient of reference gene with BestKeeper-index. 


\section{Table 5 (on next page)}

Stability values for reference genes in cubense and nitens.

Stability values for eight reference genes were obtained using three different algorithms: geNorm, NormFinder and BestKeeper. Stability values and ranking from most stable to least stable are given for each gene. A comprehensive ranking was calculated by taking the geometric mean of rankings obtained by the different algorithms. Head and thorax tissue were investigated separately. For each group, five isolated-reared and five crowded-reared last instar nymphs were used. 
1 Table 5:

2 Stability values for reference genes in cubense and nitens.

3 Stability values for eight reference genes were obtained using three different algorithms:

4 geNorm, NormFinder and BestKeeper. Stability values and ranking from most stable to least

5 stable are given for each gene. A comprehensive ranking was calculated by taking the

6 geometric mean of rankings obtained by the different algorithms. Head and thorax tissue were

7 investigated separately. For each group, five isolated-reared and five crowded-reared last instar

8 nymphs were used.

\begin{tabular}{|c|c|c|c|c|c|c|c|c|c|}
\hline \multirow[t]{2}{*}{ Species/Tissue } & \multirow[t]{2}{*}{ Gene } & \multicolumn{2}{|c|}{ geNorm } & \multicolumn{2}{|c|}{ NormFinder } & \multicolumn{3}{|c|}{ BestKeeper } & \multirow{2}{*}{$\begin{array}{c}\text { Comprehensive } \\
\text { ranking }\end{array}$} \\
\hline & & Rank & M & Rank & $\begin{array}{l}\text { Stability } \\
\text { value }\end{array}$ & Rank & $\begin{array}{l}\text { std. } \\
\text { dev. }\end{array}$ & $\mathbf{r}$ & \\
\hline \multirow{8}{*}{ cubense head } & Act5C & 1 & 0.385 & 2 & 0.097 & 2 & 0.332 & 0.896 & 1 \\
\hline & Ann & 6 & 0.540 & 7 & 0.225 & 7 & 0.457 & 0.707 & 7 \\
\hline & Arm & 5 & 0.421 & 3 & 0.111 & 1 & 0.415 & 0.905 & 3 \\
\hline & EF2 & 3 & 0.410 & 5 & 0.145 & 5 & 0.279 & 0.815 & 4 \\
\hline & GAPDH & 8 & 0.590 & 8 & 0.238 & 8 & 0.418 & 0.539 & 8 \\
\hline & Hsp70 & 2 & 0.400 & 1 & 0.095 & 3 & 0.305 & 0.872 & 2 \\
\hline & RIBL5 & 4 & 0.413 & 4 & 0.118 & 6 & 0.263 & 0.733 & 5 \\
\hline & Tub & 7 & 0.548 & 6 & 0.169 & 4 & 0.542 & 0.841 & 6 \\
\hline \multirow{8}{*}{ cubense thorax } & Act5C & 6 & 0.390 & 5 & 0.101 & 3 & 0.390 & 0.840 & 5 \\
\hline & Ann & 4 & 0.383 & 2 & 0.091 & 2 & 0.414 & 0.861 & 2 \\
\hline & Arm & 2 & 0.368 & 4 & 0.098 & 4 & 0.360 & 0.814 & 3 \\
\hline & $E F 2$ & 7 & 0.397 & 7 & 0.111 & 5 & 0.384 & 0.788 & 7 \\
\hline & GAPDH & 3 & 0.378 & 3 & 0.097 & 7 & 0.263 & 0.721 & 4 \\
\hline & Hsp70 & 1 & 0.350 & 1 & 0.075 & 1 & 0.337 & 0.893 & 1 \\
\hline & RIBL5 & 5 & 0.387 & 6 & 0.110 & 8 & 0.273 & 0.708 & 6 \\
\hline & Tub & 8 & 0.458 & 8 & 0.129 & 6 & 0.406 & 0.752 & 8 \\
\hline \multirow{8}{*}{ nitens head } & Act5C & 2 & 0.529 & 2 & 0.158 & 4 & 0.453 & 0.916 & 2 \\
\hline & Ann & 1 & 0.528 & 1 & 0.139 & 5 & 0.282 & 0.867 & 1 \\
\hline & Arm & 6 & 0.714 & 7 & 0.248 & 1 & 0.601 & 0.935 & 4 \\
\hline & $E F 2$ & 5 & 0.621 & 6 & 0.214 & 2 & 0.646 & 0.933 & 5 \\
\hline & GAPDH & 7 & 0.721 & 5 & 0.199 & 7 & 0.482 & 0.584 & 7 \\
\hline & Hsp70 & 4 & 0.578 & 3 & 0.178 & 3 & 0.539 & 0.924 & 3 \\
\hline & RIBL5 & 3 & 0.567 & 4 & 0.198 & 6 & 0.439 & 0.792 & 6 \\
\hline & Tub & 8 & 0.749 & 8 & 0.277 & 8 & 0.266 & 0.074 & 8 \\
\hline \multirow{8}{*}{ nitens thorax } & Act5C & 4 & 0.517 & 3 & 0.101 & 5 & 0.281 & 0.778 & 4 \\
\hline & Ann & 1 & 0.448 & 1 & 0.020 & 1 & 0.270 & 0.934 & 1 \\
\hline & Arm & 3 & 0.499 & 2 & 0.057 & 2 & 0.433 & 0.868 & 2 \\
\hline & $E F 2$ & 6 & 0.656 & 5 & 0.157 & 6 & 0.526 & 0.727 & 6 \\
\hline & GAPDH & 7 & 0.710 & 4 & 0.135 & 7 & 0.595 & 0.703 & 7 \\
\hline & Hsp70 & 5 & 0.549 & 6 & 0.164 & 3 & 0.449 & 0.866 & 5 \\
\hline & RIBL5 & 2 & 0.471 & 7 & 0.170 & 4 & 0.300 & 0.819 & 3 \\
\hline & Tub & 8 & 0.736 & 8 & 1.628 & 8 & 0.610 & 0.691 & 8 \\
\hline
\end{tabular}

9 M: stability value calculated by geNorm. Std. dev.: standard deviation on $\mathrm{C}_{\mathrm{T}}$ values of reference 10 gene. r: correlation coefficient of reference gene with BestKeeper-index. 


\section{Table 6(on next page)}

Comparison of target gene expression using RNA-Seq and using RT-qPCR.

Fold changes for RNA sequencing study were obtained with Deseq2 in SARTools, adjusted pvalues were obtained using default settings. Fold changes for RT-qPCR study were obtained using $\Delta \Delta \mathrm{C}_{\mathrm{T}}$ method, $\mathrm{p}$-values were obtained with a student t-test in $\mathrm{R}$. For each analysis, five isolated-reared and five crowded-reared last instar nymphs were used. For both analyses, the isolated-reared condition was used as reference. 
1 Table 6:

2 Comparison of target gene expression using RNA-Seq and using RT-qPCR.

3 Fold changes for RNA sequencing study were obtained with Deseq2 in SARTools, adjusted p4 values were obtained using default settings. Fold changes for RT-qPCR study were obtained 5 using $\Delta \Delta \mathrm{C}_{\mathrm{T}}$ method, $\mathrm{p}$-values were obtained with a student $\mathrm{t}$-test in $\mathrm{R}$. For each analysis, five 6 isolated-reared and five crowded-reared last instar nymphs were used. For both analyses, the 7 isolated-reared condition was used as reference.

8

\begin{tabular}{|l|c|c|c|c|}
\hline \multirow{2}{*}{ Gene } & \multicolumn{2}{|c|}{ RNA sequencing } & \multicolumn{2}{c|}{ RT-qPCR } \\
\cline { 2 - 5 } & Fold change & Adjusted $p$-value & Fold change & $p$-value \\
\hline ast & 0.83 & 0.865 & 0.48 & 0.018 \\
\hline at & 1.06 & 0.974 & 0.63 & 0.195 \\
\hline SPPP-4 & 2.09 & 0.029 & 2.68 & 0.032 \\
\hline SPPP-5 & 0.69 & 0.713 & 1.53 & 0.156 \\
\hline
\end{tabular}




\section{Table 7 (on next page)}

Suggestion for the use of reference genes in future RT-qPCR experiments for four Schistocerca species. 
1 Table 7:

2 Suggestion for the use of reference genes in future RT-qPCR experiments for four 3 Schistocerca species.

\begin{tabular}{|r|l|l|l|l|}
\hline \multirow{2}{*}{ Species } & Tissue & \multicolumn{3}{|c|}{ Suggested reference genes } \\
\hline \multirow{2}{*}{ piceifrons } & head & RIBL5 & Hsp70 & EF2 \\
\cline { 2 - 5 } & thorax & RIBL5 & Hsp70 & GAPDH \\
\hline \multirow{2}{*}{ americana } & head & Act5C & EF2 & \\
\cline { 2 - 5 } & thorax & RIBL5 & EF2 & \\
\hline \multirow{2}{*}{ cubense } & head & Act5C & Hsp70 & \\
\cline { 2 - 5 } & thorax & Hsp70 & Ann & \\
\hline \multirow{2}{*}{ nitens } & head & Ann & Act5C & \\
\cline { 2 - 5 } & thorax & Ann & Arm & \\
\hline
\end{tabular}

